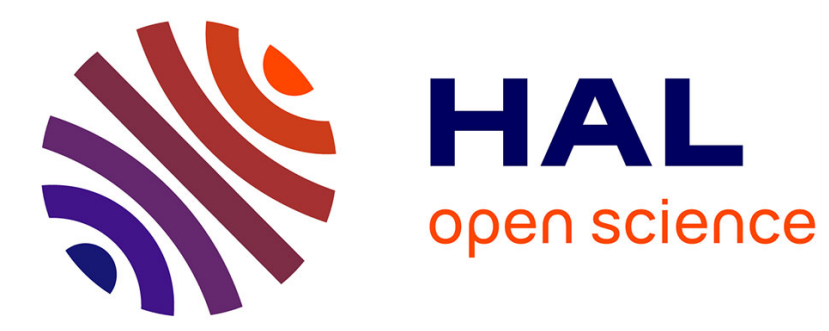

\title{
Birds and bats contribute to natural regulation of the millet head miner in tree-crop agroforestry systems
} Ahmadou Sow, Djiby Seye, Emile Faye, Laure Benoit, Maxime Galan, Julien Haran, Thierry Brévault

\section{- To cite this version:}

Ahmadou Sow, Djiby Seye, Emile Faye, Laure Benoit, Maxime Galan, et al.. Birds and bats contribute to natural regulation of the millet head miner in tree-crop agroforestry systems. Crop Protection, 2020, 132, pp.105127. 10.1016/j.cropro.2020.105127 . hal-02558065

\section{HAL Id: hal-02558065 \\ https://hal.inrae.fr/hal-02558065}

Submitted on 29 Apr 2020

HAL is a multi-disciplinary open access archive for the deposit and dissemination of scientific research documents, whether they are published or not. The documents may come from teaching and research institutions in France or abroad, or from public or private research centers.
L'archive ouverte pluridisciplinaire HAL, est destinée au dépôt et à la diffusion de documents scientifiques de niveau recherche, publiés ou non, émanant des établissements d'enseignement et de recherche français ou étrangers, des laboratoires publics ou privés.

\section{(ㅇ)(1) $\$$}

Distributed under a Creative Commons Attribution - NonCommercial - NoDerivatives| 4.0 
1 Original article: Special issue Agroforestry

2 Birds and bats contribute to natural regulation of the millet head miner in tree-

3 crop agroforestry systems

$4 \quad$ Ahmadou Sow $^{\mathrm{a} *}$, Djiby Seye ${ }^{\mathrm{a}}$, Emile Faye ${ }^{\mathrm{b}, \mathrm{c}, \mathrm{d}}$, Laure Benoit ${ }^{\mathrm{e}, \mathrm{f}}$, Maxime Galan ${ }^{\mathrm{f}, \mathrm{g}}$, Julien Haran ${ }^{\mathrm{e}, \mathrm{f}}$, Thierry

5 Brévault ${ }^{\text {h,i }}$

$6 \quad{ }^{a}$ UCAD, FST, Département de Biologie Animale, Dakar, Senegal

$7 \quad{ }^{b}$ CIRAD, UPR HortSys, Dakar, Senegal

$8{ }^{c}$ HortSys, Univ Montpellier, CIRAD, Montpellier, France

9 'ISRA, Centre pour le Développement de l'Horticulture, Dakar, Senegal

$10{ }^{e}$ CIRAD, UMR CBGP, 34398 Montpellier, France

$11{ }^{f} C B G P$, Univ Montpellier, CIRAD, INRA, IRD, Montpellier SupAgro, Montpellier, France

$12{ }^{g}$ INRA, UMR CBGP, Montpellier, France

$13{ }^{h}$ CIRAD, UPR AIDA, Centre de recherche ISRA-IRD, Dakar, Senegal

14 'AIDA, Univ Montpellier, CIRAD, Montpellier, France

15

*Corresponding author. E-mail address: s_ahmadou@yahoo.fr (Ahmadou Sow)

\section{Abstract}

19 A better understanding of environmental factors driving natural pest regulation is a major challenge for

20 designing sustainable cropping systems. The objective of the present study was to assess the association

21 between vegetation openness in traditional tree-crop agroforestry systems in Senegal, richness and 
abundance of vertebrates including insectivorous birds and bats, and their contribution to the natural regulation of crop pests. The millet head miner (MHM), Heliocheilus albipunctella (Lepidoptera, Noctuidae), a major constraint to increasing millet crop productivity in sub-Saharan Africa, was selected as a model system. Ten sites separated by at least one $\mathrm{km}$ from each other were selected in a $100 \mathrm{~km}^{2}$ study area in the Peanut basin in Senegal. In each site, a pair of millet fields distant from at least $100 \mathrm{~m}$ each was selected according to a gradient of vegetation openness within a 100-m radius buffer with sampling plot $(5 \times 5 \mathrm{~m})$ at the center. Nine insectivorous bird and bat species were recorded in millet fields over the 2017 cropping season and their predator status was confirmed by direct observation or DNA detection in fecal samples. Grain losses were reduced when panicles were accessible to birds and bats, confirming their net contribution to pest regulation. At a local scale, tree diversity and vegetation openness were important predictors of the abundance of insectivorous village weaver birds and greyheaded sparrows, respectively. Some tree species (soapberry trees and neems) indirectly contributed to natural regulation of the MHM likely by providing refuges to insectivorous vertebrates whereas other tree species (baobabs) provided disservices as possible refuges for the MHM moths. Further research is needed to better understand relationships between tree cover, food web interactions and natural pest suppression, so that specific conservation measures such as habitat management can be designed to improve pest control.

\section{Introduction}

During the last decades, worldwide losses of biodiversity have occurred at an unprecedented rate and agricultural intensification has been a major driver (Cardinale et al., 2012; Philpott et al., 2008; Tilman et al., 2002; Wilby and Thomas, 2002). The dramatic land use changes include the simplification of agricultural landscapes by deforestation and monoculture and the extensive use of agricultural inputs such as broad-spectrum insecticides to control crop pests, with detrimental impact on ecosystem health 
46 (Tscharntke et al., 2005; Barzman et al., 2015). Along with the loss of functional biodiversity, particularly

47 biological control agents, such cultivated ecosystems have become more and more susceptible to pest

48 outbreaks. This is particularly pregnant in southern contexts where arthropod pests pose a permanent

49 threat to food security (Garrity et al., 2010). New models for crop protection are needed to reduce the

50 dependence of agricultural systems on pesticides that stimulate ecological processes of natural

51 regulation of crop pests (Brévault and Clouvel, 2019). One approach is to use the benefits of agroforestry

52 systems to enhance or restore functional biodiversity (here, natural enemies of crop pests) to boost

53 ecosystem services such as biological control of crop pests. A meta-analysis conducted by Pumarino et al.

54 (2015) showed that agroforestry practices generally result in higher abundance of natural enemies of

55 pests, lower pest abundance and less plant damage in perennial crops (e.g., coffee, cocoa and plantain)

56 but not in annual crops (e.g., maize, rice and beans). However, studies carried out in Kenya showed that

57 abundance of stem borers was significantly lower in Leucaena leucocephala (Lam.) (Fabales,

58 Mimosaceae) alley cropping than in a maize monocrop (Ogol et al., 1999).

59 Among natural enemies of crop pests, vertebrates including insectivorous bats and birds can provide

60 valuable ecosystem services such as suppression of insect pests (Maas et al., 2013; Maine and Boyles,

61 2015; Pejchar et al., 2018). By protecting crops through feeding on herbivorous pests, they can provide

62 substantial increases in crop yields (Bael et al., 2008; Karp et al., 2013) and a true alternative to chemical

63 insecticides (Bianchi et al., 2006; Tscharntke et al., 2012). The abundance and diversity of semi-natural

64 habitats within agricultural landscapes, particularly trees, has the potential to increase the abundance

65 and diversity of birds and bats (Harvey et al., 2006; Redlich et al., 2018) and thus natural regulation of

66 crop pests (e.g., nesting and breeding site, alternative preys). However, birds and bats can also

67 negatively impact natural regulation of crop pests by consuming natural enemies of crop pests, i.e., intra-

68 guild predation (Grass et al. 2017; Tschumi et al., 2018). On the other hand, trees can also benefit pests

69 by providing food and refuges (Schroth et al., 2000). More research is thus needed on ecological issues 
to better understand how tree-crop agroforestry systems can contribute to enhance ecosystem services such as biological control of crop pests. Although a substantial body of research has been performed on the role of bats and birds in perennial cropping systems such as coffee plantations (Bael et al., 2008), few studies have focused on annual cropping systems as an unstable mosaic of habitats (Kennedy and Storer, 2000). More research is thus needed to deepen our knowledge of the life system of insectivorous birds and bats including seasonal population dynamics (e.g., breeding cycles, migration), multitrophic interactions within food webs (e.g. intraguild predation; see Grass et al., 2017), and temporal suitability of habitats in agricultural landscapes (Maas et al., 2016).

Agricultural landscapes in the "Peanut basin" in Senegal (West Africa) are generally structured by traditional agroforestry parkland systems (AFS), in which trees (mainly apple-ring acacias, Faidherbia albida) (Fabales, Fabaceae) are distributed in cultivated fields (Seyler, 1993). Even though the impact of those trees on soil fertility has been widely demonstrated, their effect on crop pests and biological control has been poorly studied (Hadgu et al., 2009; Umar et al., 2013). At the landscape scale, they offer a greater diversity of ecological niches in time and space than a simple mosaic of annual crops. The pearl millet, Pennisetum glaucum (L.) R. Br. (Cyperales, Poaceae), is the main annual crop in those agricultural systems. However, a key insect pest, the millet head miner (MHM) (Heliocheilus albipunctella de Joannis) (Lepidoptera, Noctuidae) is a permanent threat for increasing crop yields (Gahukar, 1984; Sow et al., 2018; Vercambre, 1978). Moths emerge from the soil one to two months after the beginning of the rainy season. After mating, females lay eggs in the millet panicle on the silk of the flower involucre or under stamens, but also on the floral peduncles or on the spine (Nwanze and Harris, 1992). The young larvae perforate the glumes and consume flowers, while the older ones cut off the floral peduncles (Gahukar, 1984; Vercambre, 1978), thus preventing grain formation. In the absence of any insecticide application by farmers, millet production relies on pest regulation by natural enemies (Bhatnagar, 1987; Nwanze and Sivakumar, 1990; Sow et al., 2019, 2017). A two-year monitoring of 90 millet fields and their surrounding 
landscape (2000 m-buffer around millet fields) showed that abundance of trees at the landscape scale significantly increased natural regulation of the MHM (Soti et al., 2019). Using high throughput molecular tools, the food web structures and ecological processes underlying natural regulation of crop pests by arthropods were documented and a large diversity of parasitoids and predators among arthropods were identified (Sow et al., 2018).

In the present study, we investigated the contribution of vertebrates, particularly insectivorous birds and bats, to the natural regulation of the MHM in tree-crop agroforestry systems in Senegal. We hypothesized that (i) abundance and diversity of trees at a local and landscape scale enhance the abundance and diversity of insectivorous birds, and that (ii) abundance and diversity of insectivorous birds at a local scale reduce pest incidence. We used satellite and drone imagery, remote sensing and geographical information system (GIS), to map and quantify the abundance and diversity of trees species at local and landscape scale around a set of 20 millet fields. Pest incidence and grain loss were evaluated by direct field observations on millet panicles while natural regulation was assessed using exclusion cages. In addition, the abundance and diversity of birds and bats was monitored in and around millet fields and fecal samples were collected to check for the presence of the MHM based on DNA analyses. Results are discussed in the light of relationships between tree diversity and abundance, role of vertebrates in food webs (ecosystem services vs. disservices) and biological control of crop pests for the deployment of ecologically-intensive cropping systems.

\section{Materials and Methods}

\subsection{Study area}

The field survey was conducted in 2017 in the northern area of the "Peanut basin", near Bambey $\left(14^{\circ} 43^{\prime} 0.79^{\prime \prime} \mathrm{N} ; 16^{\circ} 30^{\prime} 5.56^{\prime \prime} \mathrm{O}\right)$ in Senegal. This area is under the influence of a Sudano-Sahelian climate 
with a short rainy season $(400-600 \mathrm{~mm}$ ) from July to October (monsoon). The landscape is composed of tree-crop agroforestry systems mainly including apple-ring acacias (Faidherbia albida), soapberry trees

119 (Balanites aegyptica; Sapindales, Zygophyllaceae), baobabs (Adansonia digitata; Malvales, Bombacaceae), tamarinds (Tamarindus indica; Fabales, Caesalpiniaceae) and red acacias (Acacia seyal; Fabales, Fabaceae). Crops mainly include staple crops such as pearl millet, peanuts, and cowpea.

\subsection{Study design}

A total of 10 sites distant from at least one km each other (Fig. 1) were selected across the landscape

$124\left(100 \mathrm{~km}^{2}\right)$ according to the land-use proportion of tree cover (2.8-8.7\%) at a landscape scale (one-km radius buffer around millet fields), following previous treatment of very high resolution satellite imagery (Soti et al., 2018). In each site, two millet fields distant from at least $100 \mathrm{~m}$ each were selected according to vegetation openness (open vs. closed) within a $100-\mathrm{m}$ radius buffer with sampling plot $(5 \times 5 \mathrm{~m}$ ) at the center. The minimum-maximum distance between paired sampling points was $100 \mathrm{~m}$ (Fig. 1). Sampling points captured a large variation in the abundance (number of trees and land-use proportion of tree cover) and diversity (SHDI) of trees (Table 1). Tree cover around sampling plots (100-m radius buffer) was mainly composed of A. indica, B. aegyptiaca, F. albida, and A. digitata (Table 1). Situations of closed vegetation were mostly found around "compound" (close-to-home) millet fields with high abundance of neems, whereas "bush" millet fields presented more open vegetation (Fig. S1).

\subsection{Landcover mapping}

136 Drone photogrammetry and object-based image analysis procedures were used to characterize each site

137 following the method described in Sarron et al. (2018). Briefly, each site was overflowed using a UAV (DJI

138 Mavic Pro, DJI Inc, China) in order to compute a high resolution orthomosaic $\left(1.30 \mathrm{~cm}\right.$.pixel $\left.{ }^{-1}\right)$ and a

139 Canopy Height Model (CHM) using a photogrammetry procedure. The two layers were then analysed in 
eCognition Developer 9 software (Trimble Geospatial, Munich, Germany) through an object-based

141 classification workflow to obtain land cover maps. These landcover maps contained 5 object classes:

142 millet crops, bare soil, trees, grasslands, and building (Fig. 1). Tree species were manually identified

143 within the 100-m radius buffer (photointerpretation) and corrections were made when needed. Land

144 cover maps were expressed as geospatial vectors with each object, including the delineated trees,

145 corresponding to a geolocalized polygon and described in an adjunct database (.shapefile format) to be

146 imported in GIS and processed in Fragstats software (McGarigal and Marks, 1995) for spatial analysis.

\section{2.4. Data collection}

148 The incidence of the MHM was monitored in the 20 sampling plots by counting eggs on 25 randomly

149 selected panicles at panicle emergence. Counting is done with a round trip on the surface of the panicle

150 with a fine forceps. Females of the MHM usually lay their eggs on emerging panicles up to the male

151 flowering stage, between involucral bristles and glumes.

152

At the male flowering stage of millet, i.e. after completion of egg development, sampling plots were divided into two subplots of each $2.5 \times 5 \mathrm{~m}$. One subplot designated bird exclosure, while the other served as control. Bird exclosures ( $2.5 \mathrm{~m}$ height) were built with wooden frames covered with a polyethylene nylon mesh ( $25 \times 25 \mathrm{~mm}$ cell size) that allowed predatory arthropods to enter but that excluded birds. In each cage, eight panicles were protected with a mesh bag to exclude natural enemies, while 16 other panicles were left open (without mesh bag) to exclude only birds. The same design was reproduced outside the cage in the second subplot with eight panicles protected with a mesh bag to exclude natural enemies, and 16 other panicles left open as a control. As a result, a total of 960 panicles were monitored in the study design. Damages caused by the MHM (number and length of mines) were recorded from each panicle just before harvest, i.e., 21 days later. Conversion of damages to grain losses was done using allometric relations (Thiaw et al., 2017). 
163 Field monitoring of birds and bats was performed on the five sites located in the southern part of the

164 study area, over a period of 15 days (3 days in each site) from millet grain filling to maturity.

165 Observations of birds were carried out around sampling plots in the morning (7.00 to 9.00 am UTC) and 166 in the late afternoon (4.30 to $6.30 \mathrm{pm}$ UTC). The species and food diet (millet grain vs. MHM larvae) of

167 birds observed on millet panicles were recorded. Bird abundance in millet fields was calculated by using

168 the frequency of occurrence $(C)$ proposed by Linsdale (1928). Bird species were identified using the

169 "Guide of West African birds" (Borrow and Demey, 2015). Bats were counted at regular time intervals (5

$170 \mathrm{~min}$ ) at dusk (from 6.30 to $7.40 \mathrm{pm}$ UTC).

$171 \quad$ 2.5. Analysis of fecal samples

172 To check the predation of the MHM by vertebrates, fecal samples of the village weaver (Ploceus

173 cucullatus; Passeriformes, Ploceidae) and the Mauritian tomb bat (Taphozous mauritianum; Chiroptera,

174 Emballonuridae) were collected during 24 hours by using a plastic tarpaulin placed under nesting trees,

175 neem (Azadirachta indica; Sapindales, Meliaceae) and palm trees (Borassus aethiopum; Arecales,

176 Arecaceae), respectively. Samples were collected at three millet phenological stages corresponding to

177 successive development of the immature stages of the MHM: (1) panicle emergence to female flowering

178 for eggs, (2) panicles with grains at the milk stage for the $1^{\text {st }}$ and $2^{\text {nd }}$ instar larvae, and (3) panicles with

179 grains at the dough stage for $3^{\text {rd }}$ and $4^{\text {th }}$ instar larvae, from late August to late September. A total of 80

180 and 92 fecal samples for birds and bats, respectively, were individually collected using clean cotton buds

181 and placed in 2-ml microtubes with silica-gel granules to absorb moisture and prevent the development

182 of molds and DNA degradation. Detection of the MHM in fecal samples was performed by amplification

183 of the $133 \mathrm{bp}$ fragment of cytochrome c oxidase I (COI mini-barcode, Gillet et al., 2015) and sequencing

184 on a MiSeq Illumina platform (Appendix A). 


\subsection{Statistical analyses}

The R program (version 3.6.1) was used for statistical analyses ( $R$ Core team, 2014). We used generalized linear models ( $g / m$ function from the MASS package) to test the effect of bird abundance and diversity on pest incidence (including the number of eggs per panicle and grain loss). Models were fitted using the appropriate distribution type and link function: binomial for proportion of infested panicles or grain loss (link $=$ logit), and Poisson for abundance (count data, link $=\log )$. We then tested with the same type of models the effect of tree cover at a local and landscape scale on the abundance and diversity of birds, and on pest incidence. Multi-model inference approach was performed to examine the relative importance of each explanatory variable (Burnham and Anderson, 2002). The MuMIn package was used to perform model selection and model averaging. Akaike weights were calculated according to the Akaike information criterion (AICC) which is a bias-corrected version of the AIC recommended in analyses where the sample size is small relative to the number of fitted parameters (Burnham and Anderson, 2002; Rusch et al., 2011; Soti et al., 2019). The indirect effect of natural enemy exclosure (three treatments: mesh bag, cage, and open as control) on grain loss was analysed using a linear mixed model (Imer function in the Ime4 package) with site as a random effect to account for the variation due to this factor. Multiple post-hoc comparisons were carried out with Tukey contrasts using the glht function from the multcomp package.

\section{Results}

\subsection{Abundance and diversity of insectivorous birds and bats}

Sampling points captured a large variation in the abundance (number) and diversity (SHDI) of observed birds (Table 1). A total of eight insectivorous birds belonging to five families (Corvidae, Passeridae, Ploceidae, Pycnonotidae and Sturnidae) were observed in millet fields (Table 2). The grey-headed sparrow (Passer griseus, Passeriformes, Passeridae), the village weaver (P. cuculatus), and the little weaver (Ploceus luteolus; Passeriformes, Ploceidae) were the most frequently observed species (Table 2). 
The frequency of occurrence of the five other bird species observed was very low (<3\%). Direct field observations showed that the encountered bird species were omnivorous (both granivorous and insectivorous), except Lamprotornis pulcher (Muller) (Passeriformes, Sturnidae) which was observed

212 feeding exclusively on insects. We identified two bat species foraging around millet sampling plots: a

213 frugivorous species, the African straw-colored fruit bat (Eidolon helvum; Chiroptera, Pteropodidae) and 214 an insectivorous species, the Mauritian tomb bat (T. mauritianus) (Table 2).

215 Using a metabarcoding approach, we successfully detected DNA sequences of the MHM in fecal samples

216 of the village weaver bird and the Mauritian tomb bat. The frequency of detection of the MHM DNA in

217 fecal samples from village weavers indicated that these birds primarily feed on late instar larvae (Fig. 2).

218 Detection of the MHM DNA in bats indicated that they feed on MHM moths (egg oviposition period) and 219 probably also on late instar larvae.

\subsection{Effect of tree cover on insectivorous birds}

221 The diversity of trees was the most important predictor explaining the abundance of birds observed in and around millet sampling plots (Fig. 3A). The abundance of birds increased with the diversity of trees in a 100-m radius around sampling plots. The abundance of the village weavers followed the same trend, whereas the abundance of the grey-headed sparrow was negatively correlated to the abundance of trees

225 (Fig. 3B, 3C). No effect of tree cover on the abundance or diversity of birds was detected at a landscape scale (1000 and 1750-m radius buffer around sampling points). Direct field observations showed that

227 palm trees served as preferential nesting site for the Mauritian tomb bat.

\section{3.3. Effect of insectivorous vertebrates on pest incidence}

229 The MHM incidence in millet fields was generally high (53.4\% egg-infested panicles, 96\% damaged 230 panicles), but variable among fields (24-80\% egg-infested panicles, $87-100 \%$ damaged panicles). Grain 231 losses due to the MHM varied from 9.7 to $29.3 \%$ among sampling plots (Table 1 ). The abundance and 
diversity of birds did not contribute significantly in explaining pest incidence levels (Fig. 4). Grain loss was significantly reduced when panicles were accessible to arthropods only $(-17.4 \%)$, and even more $(-35.7 \%)$ when they were accessible to both arthropods and birds (Fig. 5).

\subsection{Effect of tree cover on MHM incidence}

The abundance of baobabs at a local scale, i.e., 100-m radius buffer around sampling plots, increased MHM egg infestation on panicles and grain losses (Fig. 6). Conversely, the abundance of soapberry trees in the same area decreased egg infestation and grain losses, whereas the abundance of neems decreased egg infestation only (Fig. 6). Egg infestation and grain loss did not depend on the abundance or diversity of trees at a landscape scale.

\section{Discussion}

Among natural enemies of crop pests, vertebrates including insectivorous bats and birds can provide valuable ecosystem services such as suppression of insect pests, particularly in agroforestry systems (Karp et al., 2013, 2016; Maas et al., 2013; Maine and Boyles, 2015). However, they can also disrupt natural pest regulation by intraguild competition with predatory arthropods in agroecosystems (Grass et al., 2017; Martin et al., 2013). In the present study, we investigated the association between vegetation openness, richness and abundance of insectivorous birds and bats, and their contribution to the natural regulation of the MHM in tree-crop agroforestry systems in Senegal.

The exclusion of natural enemies including arthropods and vertebrates from millet panicles showed that grain losses significantly decreased when panicles were accessible to arthropods only, and even more when they were accessible to both arthropods and birds. We did not observed significant damage on millet panicles due to seed predation by granivorous birds. The vertebrate predatory community was composed of eight bird species of Passeriformes mostly represented by weavers (Ploceus spp.) and sparrows (Passer griseus). Direct field observations showed that encountered bird species were both 
granivorous and insectivorous, except L. pulcher, which was observed feeding exclusively on insects. Two

256

257

258

259

260

261 bat species were seen foraging in the surrounding environment of millet sampling plots: a frugivorous species, the African straw-colored fruit bat (Eidolon helvum) and an insectivorous species, the Mauritian tomb bat (Taphozous mauritianus). The analysis of fecal samples of birds and bats indicated that village weavers primarily fed on late instar larvae, whereas bats fed on MHM moths (egg oviposition period) and probably also on late instar larvae. According to Goodman et al. (2007), the Mauritian tomb bat is a nocturnal hunter, with moths as preferred food, though during daylight hours they can occasionally prey upon butterflies and termites. The Mauritian tomb bat possibly contributes more than birds to the natural regulation of MHM populations, because unlike birds, insectivorous bats can feed on a large quantity of moths (Kingdon, 1974), thus limiting egg-laying on millet panicles. Birds can exert high predation on MHM larvae during the reproductive season to feed their chicks. Contrary to adults who feed mainly on seeds to which they add insects, chicks feed exclusively on insects including lepidopteran larvae (Bruggers et al., 1985; Petersen et al., 2007).

The abundance and diversity of natural habitats in agroforestry systems is a key factor for the conservation of natural enemies, particularly vertebrates in agricultural landscapes (Bianchi et al., 2006; Holland et al., 2016; Rusch et al., 2016). The positive impact of trees species richness on bats and insectivorous birds communities in agricultural landscape has been demonstrated (Harvey et al., 2006). In our study, the abundance of birds (all species together) was positively related to the diversity of trees around millet sampling plots. Populations of village weavers showed the same trend, whereas greyheaded sparrows were preferentially observed in open habitats. Village weavers are gregarious (Collias and Collias, 1970) and their colonies settle a few weeks after the start of the rainy season, just before the emergence of millet panicles (Bruggers et al., 1985). They build their nests on different tree species (mainly neems, palm trees, and balanites) located near residential areas and forage in neighbor millet fields to collect insects, particularly late instar larvae on panicles at the time of chick breeding. Unlike the 
village weaver, the grey-headed sparrow is solitary and it can be encountered in a wide range of open

280

281 habitats, including open woodlands and human habitation. No effect of tree cover was detected at a landscape scale (1000 and 1750-m radius buffer around sampling points), indicating short-distance interaction of insectivorous birds with the surrounding landscape. Direct field observations showed that palm trees served as preferential nesting site for the Mauritian tomb bat. The species is characterized by very effective hunting aptitudes including excellent vision, nocturnal hunting, echolocation of prey, and fast flight (Fenton, 1990; Dengis, 1996), which make it an excellent predator of noctuid moths. Their hunting season coincides with the moment when MHM females leave their shelter sites at dusk to lay eggs on millet heads. Our field observations revealed that this generalist predator was able to hunt insects under the street lights in villages, in addition to its ability to hunt effectively in total darkness (A. Sow, unpublished data).

When addressing the effect of tree cover on the incidence of MHM, we found that relative contribution of trees to natural pest regulation was probably species-dependent. In the present study, we observed a negative effect of the abundance of soapberry trees and neems on egg infestation. As these trees are often used as nesting sites by village weaver colonies, MHM moths could have been deterred from resting on such trees, as the analysis of fecal samples indicated that those birds primarily feed on late instar larvae. An alternative hypothesis is that soapberry trees and neems offer refuges for other natural enemies groups capable of affecting pest incidence through the direct consumption of eggs (e.g., predatory arthropods) or moths (e.g., bats). On the other hand, the presence of certain tree species can negatively affect crop yield by increasing the population density of the pest (Schroth et al., 2000). This is possibly the case for baobabs, as our results showed that MHM incidence (egg infestation on panicles and grain losses) increased with baobab density at a local scale. Baobabs could provide resources for insect pests, such as refuges and food. 


\section{Conclusion}

The present study provides key information on hypotheses addressed about the link between abundance and diversity of trees at a local and landscape scale and the abundance and diversity of insectivorous birds and bats, and their net contribution to natural pest control and reduction of millet grain loss. At a local scale, the abundance of insectivorous village weaver birds increased with tree diversity whereas that of grey-headed sparrows decreased with the abundance of trees. Results also showed that trees indirectly contribute to natural regulation of the MHM likely by providing refuges to insectivorous vertebrates (e.g., palms/bats or neems/village weavers). However, other tree species can provide disservices as refuges for pests (e.g., baobabs/MHM moths). To capture the variability of such natural pest regulation and the effects of environmental perturbations (climate, land use, deforestation, pesticides, etc.), it would be relevant to carry out this study on a pluriannual scheme. More research is also needed to deeply examine the links between tree species (habitats), natural enemies (taxonomic and functional traits of communities), pest regulation (e.g., intraguild predation, temporal dynamics) and crop yield. This should assist the design of specific conservation measures such as habitat management to promote conservation biological control. Next steps include farmer-participatory approaches to design farmscapes fostering natural pest regulation.

\section{Acknowledgements}

This work was undertaken as part of, and funded by the CGIAR Research Program on Grain Legumes and Dryland Cereals (Program FP3-3.3, Managing functional biodiversity and crop pests) and supported by CGIAR Fund Donors. Funding support for this study was also provided by CIRAD (Action incitative CreSi 2017). We are grateful to Amadou R.A. Etikokou for assistance to statistical analyses. 
325 The authors declare no competing interests.

\section{References}

Bael, S.A.V., Philpott, S.M., Greenberg, R., Bichier, P., Barber, N.A., Mooney, K.A., Gruner, D.S., 2008. Birds as predators in tropical agroforestry systems. Ecology 89, 928-934.

Barzman, M., Bàrberi, P., Birch, A.N.E., Boonekamp, P., Dachbrodt-Saaydeh, S., Graf, B., Hommel, B., Jensen, J.E., Kiss, J., Kudsk, P., Lamichhane, J.R., Messéan, A., Moonen, A.-C., Ratnadass, A., Ricci, P., Sarah, J.-L., Sattin, M., 2015. Eight principles of integrated pest management. Agronomy for Sustainable Development 35, 1199-1215.

Bhatnagar, V.S., 1987. Conservation and encouragement of natural enemies of insect pests in dryland subsistence farming: Problems, progress and prospects in the Sahelian zone. International Journal of Tropical Insect Science 8, 791-795.

Bianchi, F.J.J.A., Booij, C.J.H., Tscharntke, T., 2006. Sustainable pest regulation in agricultural landscapes: a review on landscape composition, biodiversity and natural pest control. Proceedings of the Royal Society B: Biological Sciences 273, 1715-1727.

Borrow, N., Demey, R., 2015. Guide des oiseaux de l'Afrique de l'Ouest. Delachaux et Niestlé. Paris.

Brévault, T., Clouvel, P., 2019. Pest management: Reconciling farming practices and natural regulations. Crop Protection 115, 1-6.

Bruggers, R.L., Jaeger, M.E., Jaeger, M.M., 1985. Tisserins gendarmes (Ploceus cucullatus abyssinicus) et tisserins masqués (Ploceus intermedius intermedius) munis d'émetteurs radio et de rubans dans une colonie de nidification du Sud de l'Ethopie. L'Oiseau et la Revue française d'ornithologie 55, 81-92. 
Burnham, K. P., Anderson, D. R., 2004. Multimodel inference: understanding AIC and BIC in model selection. Sociological Methods and Research 33, 261-304.

Cardinale, B.J., Duffy, J.E., Gonzalez, A., Hooper, D.U., Perrings, C., Venail, P., Narwani, A., Mace, G.M., Tilman, D., Wardle, D.A., Kinzig, A.P., Daily, G.C., Loreau, M., Grace, J.B., Larigauderie, A., Srivastava, D.S., Naeem, S., 2012. Biodiversity loss and its impact on humanity. Nature 486, 59-67.

Collias, N.E., Collias, E.C., 1967. A Quantitative Analysis of Breeding Behavior in the African Village Weaverbird. The Auk 84, 396-411.

Dengis, C. A., 1996. Taphozous mauritianus. Mammalian Species 522, 1-5.

Fenton, M. B., 1990. The foraging behaviour and ecology of animal-eating bats. Canadian Journal of Zoology 68, 411-422.

Gahukar, R.T., 1984. Insect pests of pearl millet in West Africa: a review. International Journal of Pest Management 30, 142-147.

Garrity, D.P., Akinnifesi, F.K., Ajayi, O.C., Weldesemayat, S.G., Mowo, J.G., Kalinganire, A., Larwanou, M., Bayala, J., 2010. Evergreen Agriculture: a robust approach to sustainable food security in Africa. Food Security 2, 197-214.

Gillet, F., Tiouchichine, M.-L., Galan, M., Blanc, F., Némoz, M., Aulagnier, S., Michaux, J.R., 2015. A new method to identify the endangered Pyrenean desman (Galemys pyrenaicus) and to study its diet, using next generation sequencing from faeces. Mammalian Biology - Zeitschrift für Säugetierkunde $80,505-509$.

Grass, I., Lehmann, K., Thies, C., Tscharntke, T., 2017. Insectivorous birds disrupt biological control of cereal aphids. Ecology 98, 1583-1590.

Hadgu, K.M., Kooistra, L., Rossing, W.A.H. et al. 2009. Assessing the effect of Faidherbia albida based land use systems on barley yield at field and regional scale in the highlands of Tigray, Northern Ethiopia. Food Security 1, 337-350. 
Harvey, C.A., Medina, A., Sánchez, D.M., Vílchez, S., Hernández, B., Saenz, J.C., Maes, J.M., Casanoves, F., Sinclair, F.L., 2006. Patterns of Animal Diversity in Different Forms of Tree Cover in Agricultural Landscapes. Ecological Applications 16, 1986-1999.

Holland, J.M., Bianchi, F.J., Entling, M.H., Moonen, A.-C., Smith, B.M., Jeanneret, P., 2016. Structure, function and management of semi-natural habitats for conservation biological control: a review of European studies. Pest management science 72, 1638-1651.

Karp, D.S., Mendenhall, C.D., Sandí, R.F., Chaumont, N., Ehrlich, P.R., Hadly, E.A., Daily, G.C., 2013. Forest bolsters bird abundance, pest control and coffee yield. Ecology letters 16, 1339-1347.

Kennedy, G. G., Storer, N. P., 2000. Life systems of polyphagous arthropod pests in temporally unstable cropping systems. Annual Review of Entomology 45, 467-493.

Kingdon, J., 1974. East African Mammals: An Atlas of Evolution in Africa, Academic Press. ed. Jonathan Kingdon, London.

Linsdale, J.M., 1928. A Method of Showing Relative Frequency of Occurrence of Birds. The Condor 30, 180-184.

Maas, B., Clough, Y., Tscharntke, T., 2013. Bats and birds increase crop yield in tropical agroforestry landscapes. Ecology letters 16, 1480-1487.

Maas, B., Karp, D.S., Bumrungsri, S., Darras, K., Gonthier, D., Huang, J.C.-C., Lindell, C.A., Maine, J.J., Mestre, L., Michel, N.L., Morrison, E.B., Perfecto, I., Philpott, S.M., Şekercioğlu, C..H., Silva, R.M., Taylor, P.J., Tscharntke, T., Bael, S.A.V., Whelan, C.J., Williams-Guillén, K., 2016. Bird and bat predation services in tropical forests and agroforestry landscapes. Biological Reviews 91, 10811101.

McGarigal, K., Marks, B.J., 1995. FRAGSTATS: spatial pattern analysis program for quantifying landscape structure. Gen. Tech. Rep. PNW-GTR-351. U.S. Department of Agriculture, Forest Service, Pacific Northwest Research Station, Portland, Oregon, USA, 122 pp. 
Maine, J.J., Boyles, J.G., 2015. Bats initiate vital agroecological interactions in corn. Proceedings of the National Academy of Sciences USA 112, 12438-12443.

Martin, E.A., Reineking, B., Seo, B., Steffan-Dewenter, I., 2013. Natural enemy interactions constrain pest control in complex agricultural landscapes. Proceedings of the National Academy of Sciences USA 110, 5534-5539.

Nwanze, K.F., Harris, K.M., 1992. Insect pests of pearl millet in West Africa. Review of Agricultural Entomology 80, 1132-1155.

Nwanze, K.F., Sivakumar, M.V.K., 1990. Insect pests of pearl millet in Sahelian West Africa-II. Raghuva albipunctella De Joannis (Noctuidae, Lepidoptera): Distribution, population dynamics and assessment of crop damage. Tropical Pest Management 36, 59-65.

Ogol, C.K.P.O., Spence, J.R., Keddie, A., 1999. Maize stem borer colonization, establishment and crop damage levels in a maize-leucaena agroforestry system in Kenya. Agriculture, Ecosystems and Environment 76, 1-15.

Pejchar, L., Gallo, T., Hooten, M.B., Daily, G.C., 2018. Predicting effects of large-scale reforestation on native and exotic birds. Diversity and Distributions 24, 811-819.

Petersen, B.S., Christensen, K.D., Jensen, F.P., 2007. Bird population densities along two precipitation gradients in Senegal and Niger. Malimbus 29, 101-121.

Philpott, S.M., Arendt, W.J., Armbrecht, I., Bichier, P., Diestch, T.V., Gordon, C., Greenberg, R., Perfecto, I., REYNOSO-SANTOS, R., SOTO-PINTO, L., 2008. Biodiversity loss in Latin American coffee landscapes: review of the evidence on ants, birds, and trees. Conservation Biology 22, 1093-1105. Pumariño, L., Sileshi, G.W., Gripenberg, S., Kaartinen, R., Barrios, E., Muchane, M.N., Midega, C., Jonsson, M., 2015. Effects of agroforestry on pest, disease and weed control: A meta-analysis. Basic and Applied Ecology 16, 573-582. 
R Core Team, 2014. R: A language and environment for statistical computing. R Foundation for Statistical Computing, Vienna, Austria. URL http://www.R-project.org/

Redlich, S., Martin, E.A., Wende, B., Steffan-Dewenter, I., 2018. Landscape heterogeneity rather than crop diversity mediates bird diversity in agricultural landscapes. PloS one 13, e0200438.

Rusch, A., Valantin-Morison, M., Sarthou, J. P., \& Roger-Estrade, J., 2011. Multi-scale effects of landscape complexity and crop management on pollen beetle parasitism rate. Landscape Ecology 26, $473-$ 486.

Rusch, A., Chaplin-Kramer, R., Gardiner, M.M., Hawro, V., Holland, J., Landis, D., Thies, C., Tscharntke, T., Weisser, W.W., Winqvist, C., 2016. Agricultural landscape simplification reduces natural pest control: A quantitative synthesis. Agriculture, Ecosystems and Environment 221, 198-204.

Sarron, J., Malézieux, ., Sané, C.A.B., Faye, É., 2018. Mango Yield Mapping at the Orchard Scale Based on Tree Structure and Land Cover Assessed by UAV. Remote Sensing 10, 1900.

Schroth, G., Krauss, U., Gasparotto, L., Aguilar, J.A.D., Vohland, K., 2000. Pests and diseases in agroforestry systems of the humid tropics. Agroforestry Systems 50, 199-241.

Seyler, J.R., 1993. A systems analysis of the status and potential of Acacia Albida (Del.) in the North Central Peanut Basin of Senegal. Michigan State University. Department of Forestry. $30 \mathrm{p}$.

Soti, V., Lelong, C., Goebel, F.-R., Brévault, T., 2018. Designing a field sampling plan for landscape-pest ecological studies using VHR optical imagery. International Journal of Applied Earth Observation and Geoinformation 72, 26-33.

Soti, V., Thiaw, I., Debaly, Z.M., Sow, A., Diaw, M., Fofana, S., Diakhate, M., Thiaw, C., Brévault, T., 2019. Effect of landscape diversity and crop management on the control of the millet head miner, Heliocheilus albipunctella (Lepidoptera: Noctuidae) by natural enemies. Biological Control 129, $115-122$. 
440

441

442

443

444

445

446

447

448

449

450

451

455

456

457

458

459

460

461

462

463

Sow, A., Brévault, T., Benoit, L., Chapuis, M.-P., Galan, M., D’acier, A.C., Delvare, G., Sembène, M., Haran, J., 2019. Deciphering host-parasitoid interactions and parasitism rates of crop pests using DNA metabarcoding. Scientific Reports 9, 3646.

Sow, A., Brévault, T., Delvare, G., Haran, J., Benoit, L., Coeur d'Acier, A., Galan, M., Thiaw, C., Soti, V., Sembène, M., 2018. DNA sequencing to help identify crop pests and their natural enemies in agroecosystems: the case of the millet head miner Heliocheilus albipunctella (Lepidoptera: Noctuidae) in sub-Saharan Africa. Biological Control 121, 199-207.

Sow, A., Brévault, T., Delvare, G., Haran, J., Mbacké, S., 2017. Régulation naturelle des populations de la mineuse de la chandelle de mil, Heliocheilus albipunctella (Lepidoptera, Noctuidae), dans le bassin arachidier au Sénégal. AFPP, CIRAA 1-9.

Thiaw, C., Brévault, T., Diallo, N. F., Sow, A., Ngom, D., Soti et al. 2017. Incidence et régulation naturelle de la chenille mineuse de l'épi de mil, Heliocheilus albipunctella de Joannis (Lepidoptera, Noctuidae) à Bambey dans le bassin arachidier au Sénégal. Agronomie Africaine 29, 83-95.

Tilman, D., Cassman, K.G., Matson, P.A., Naylor, R., Polasky, S., 2002. Agricultural sustainability and intensive production practices. Nature $418,671-677$.

Tschumi, M., Ekroos, J., Hjort, C., Smith, H. G., \& Birkhofer, K., 2018. Rodents, not birds, dominate predation-related ecosystem services and disservices in vertebrate communities of agricultural landscapes. Oecologia 188, 863-873.

Tscharntke, T., Klein, A.M., Kruess, A., Steffan-Dewenter, I., Thies, C., 2005. Landscape perspectives on agricultural intensification and biodiversity-ecosystem service management. Ecology letters 8, 857-874.

Umar, B. B., Aune, J. B., \& Lungu, O. I., 2013. Effects of Faidherbia albida on the fertility of soil in smallholder conservation agriculture systems in eastern and southern Zambia. African Journal of Agricultural Research 8, 173-183. 
464 Vercambre, B., 1978. Raghuva spp. et Masalia sp., chenilles des chandelles du mil en zone sahélienne.

$465 \quad$ Agronomie Tropicale 33, 62-79.

466 Wilby, A., Thomas, M.B., 2002. Natural enemy diversity and pest control: patterns of pest emergence 467 with agricultural intensification. Ecology Letters 5, 353-360.

468

469

470 


\section{Figure captions}

474

475

Figure 1. Map of the 20 paired millet sampling plots within the study area (Bambey, Senegal). Example (on the right) of a digitized landscape around one sampling plot.

Figure 2. Detection rate (\%) of the millet head miner DNA in bird (Ploceus cucullatus) and bat (Taphozous mauritianus) fecal samples collected at different phenological stages of the millet crops corresponding to the presence of different development stages of the millet head miner (moths and eggs, moths and early instar larvae, late instar larvae). Bars represent the 95\% confidence intervals (CI95).

Figure 3. Relative importance of the abundance and diversity of trees (at a 100-m radius buffer around sampling plots) in explaining variation of $(A)$ the abundance of birds, $(B)$ the abundance of the greyheaded sparrow, and $(C)$ the abundance of the village weaver. Variables were ranked according to their sum of Akaike weights, which are the probabilities that the given predictor would appear in the best fitting model. Black bars indicate the most important variables. Estimated parameter values and their their standard error (SE) are presented on the right of each bar.

Figure 4. Relative importance of the abundance and diversity of birds (at a 100-m radius buffer around sampling plots) in explaining variation of $(A)$ egg infestation and (B) grain losses due to the millet head miner (MHM). Variables were ranked according to their sum of Akaike weights $(w+(j))$, which are the probabilities that the given predictor would appear in the best fitting model. Estimated parameter values and their standard error (SE) are presented on the right of each bar. 
491 Figure 5. Grain loss (\%) on egg-infested panicles (i) covered with a mesh bag to exclude natural enemies,

492 (ii) covered with a polyethylene nylon mesh $(25 \times 25 \mathrm{~mm}$ cell size) to exclude vertebrates but not

493 predatory arthropods or parasitoids, or (iii) exposed to both parasitoids, predatory arthropods and

494 vertebrates (open panicles). Means followed by different letters are significantly different (post hoc

495 Tukey test). Mean grain ( \pm SE) loss: mesh bag $(26.3 \pm 1.4 \%)$, cage $(21.7 \pm 1.3 \%)$ and open control $(16.9 \pm$

496 1.1\%).

497 Figure 6. Relative importance of the abundance and diversity of trees (at a 100-m radius buffer around

498 sampling plots) in explaining variation of (A) egg infestation and (B) grain losses due to the millet head

499 miner (MHM). Variables were ranked according to their sum of Akaike weights $(w+(j))$, which are the

500 probabilities that the given predictor would appear in the best fitting model. Black bars indicate the most

501 important variables. Estimated parameter values and their standard error (SE) are presented on the right

502 of each bar. 
Table 1. Tree cover and diversity, bird abundance and diversity, and pest incidence of the 20 sampling plots in the study area. Tree cover is characterized at the local (100-m radius buffer around sampling plots) and landscape scale (1-km radius buffer around sampling plots).

\begin{tabular}{|c|c|c|c|}
\hline Variables & & $\begin{array}{c}\text { Range } \\
\text { (min-max) }\end{array}$ & Mean $\pm \mathrm{Cl} 95$ \\
\hline \multicolumn{4}{|l|}{ Tree cover } \\
\hline \multirow[t]{8}{*}{ At a local scale } & Tree cover (\%) & $3.5-18.3$ & $9.3 \pm 1.8$ \\
\hline & Number of trees & $21-94$ & $52.3 \pm 9.3$ \\
\hline & Number of Azadirachta indica & $0-53$ & $15.8 \pm 6.5$ \\
\hline & Number of Balanites aegyptiaca & $0-29$ & $13.4 \pm 3.2$ \\
\hline & Number of Faidherbia albida & $2-18$ & $8.2 \pm 1.9$ \\
\hline & Number of Adansonia digitata & $0-31$ & $8.3 \pm 3.7$ \\
\hline & Number of Borassus aethiopium & $0-7$ & $1.3 \pm 0.8$ \\
\hline & Tree SHDI & $0.9-1.7$ & $1.3 \pm 0.1$ \\
\hline At a landscape scale & Tree cover (\%) & $2.8-8.7$ & $5.7 \pm 1.0$ \\
\hline \multicolumn{4}{|c|}{ Bird abundance and diversity } \\
\hline & Number of birds per sampling plot & $1-83$ & $49 \pm 18$ \\
\hline & Bird SHDI & $0.0-1.3$ & $0.9 \pm 0.3$ \\
\hline \multicolumn{4}{|l|}{ Pest incidence } \\
\hline & Egg infested panicles (\%) & $24.0-80.0$ & $53.4 \pm 6.8$ \\
\hline & Number of eggs per panicle & $0.4-3.8$ & $1.9 \pm 0.4$ \\
\hline & Damaged panicles (\%) & $86.7-100$ & $96.2 \pm 1.9$ \\
\hline & Grain loss $(\%)$ & $9.7-29.3$ & $16.9 \pm 2.1$ \\
\hline
\end{tabular}


Table 2. Inventory of major birds and bats observed in millet-based agroecosystems in the North of the Peanut basin in Senegal.

\begin{tabular}{|c|c|c|c|c|c|c|}
\hline $\begin{array}{l}\text { Order } \\
\text { Family }\end{array}$ & Common name & Latin name & $\begin{array}{l}\text { Food } \\
\text { diet }\end{array}$ & $\begin{array}{l}\text { Frequency of } \\
\text { occurrence (\%) }\end{array}$ & $\begin{array}{c}\text { Relative } \\
\text { abundance } \\
(\%)\end{array}$ & $\begin{array}{l}\text { *Predat } \\
\text { ion } \\
\text { evidenc }\end{array}$ \\
\hline Passeriformes & & & & & & e on \\
\hline Corvidae & African piapiac & Ptilostomus afer (Swainson, 1837)* & I/G & 0.4 & 1.5 & MHM \\
\hline Passeridae & Grey-headed sparrow & Passer griseus (Vieillot, 1817)* & I/G & 32.5 & 42.6 & by \\
\hline \multirow[t]{2}{*}{ Ploceidae } & Village weaver & Ploceus cucullatus (Statius Müller, PL, 1776)** & I/G & 34.2 & 37.4 & direct \\
\hline & Little weaver & Ploceus luteolus (Lichtenstein, MHK, 1823)* & $\mathrm{I} / \mathrm{G}$ & 17.1 & 12.3 & observa \\
\hline Pycnonotidae & Common bulbul & Pycnonotus barbatus (Desfontaines, 1789)* & I/G & 2.5 & 1.9 & **Pred \\
\hline \multirow[t]{3}{*}{ Sturnidae } & Long-tailed glossy starling & Lamprotornis caudatus (Statius Müller, 1776)* & $\mathrm{I} / \mathrm{G}$ & 0.4 & 3.3 & ation \\
\hline & Chestnut-bellied starling & Lamprotornis pulcher (Müller, 1776)* & 1 & 0.8 & 0.4 & evidenc \\
\hline & Lesser blue-eared starling & Lamprotornis chloropterus (Swainson, 1838)* & $\mathrm{I} / \mathrm{G}$ & 0.8 & 0.6 & $\begin{array}{l}\text { e on } \\
\text { MHM }\end{array}$ \\
\hline Chiroptera & & & & & & confirm \\
\hline Pteropodidae & African straw-colored fruit bat & Eidolon helvum (Kerr, 1792)** & $\mathrm{F}$ & - & - & ed by \\
\hline Emballonuridae & Mauritian tomb bat & Taphozous mauritianus (E. Geoffroy, 1818)** & I & - & - & molecul \\
\hline
\end{tabular}

analysis. I: insectivorous. F: frugivorous. G: granivorous. 
Journal Pre-proof
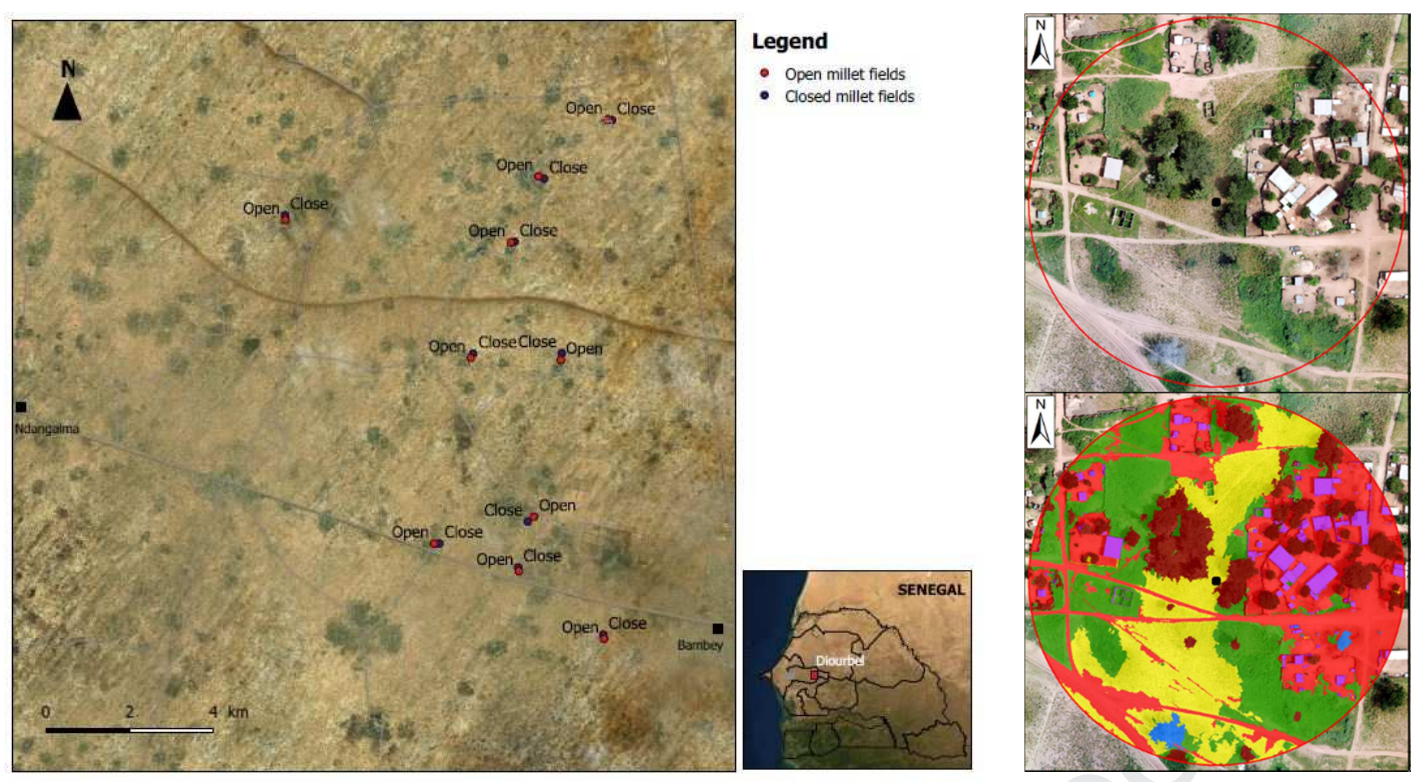


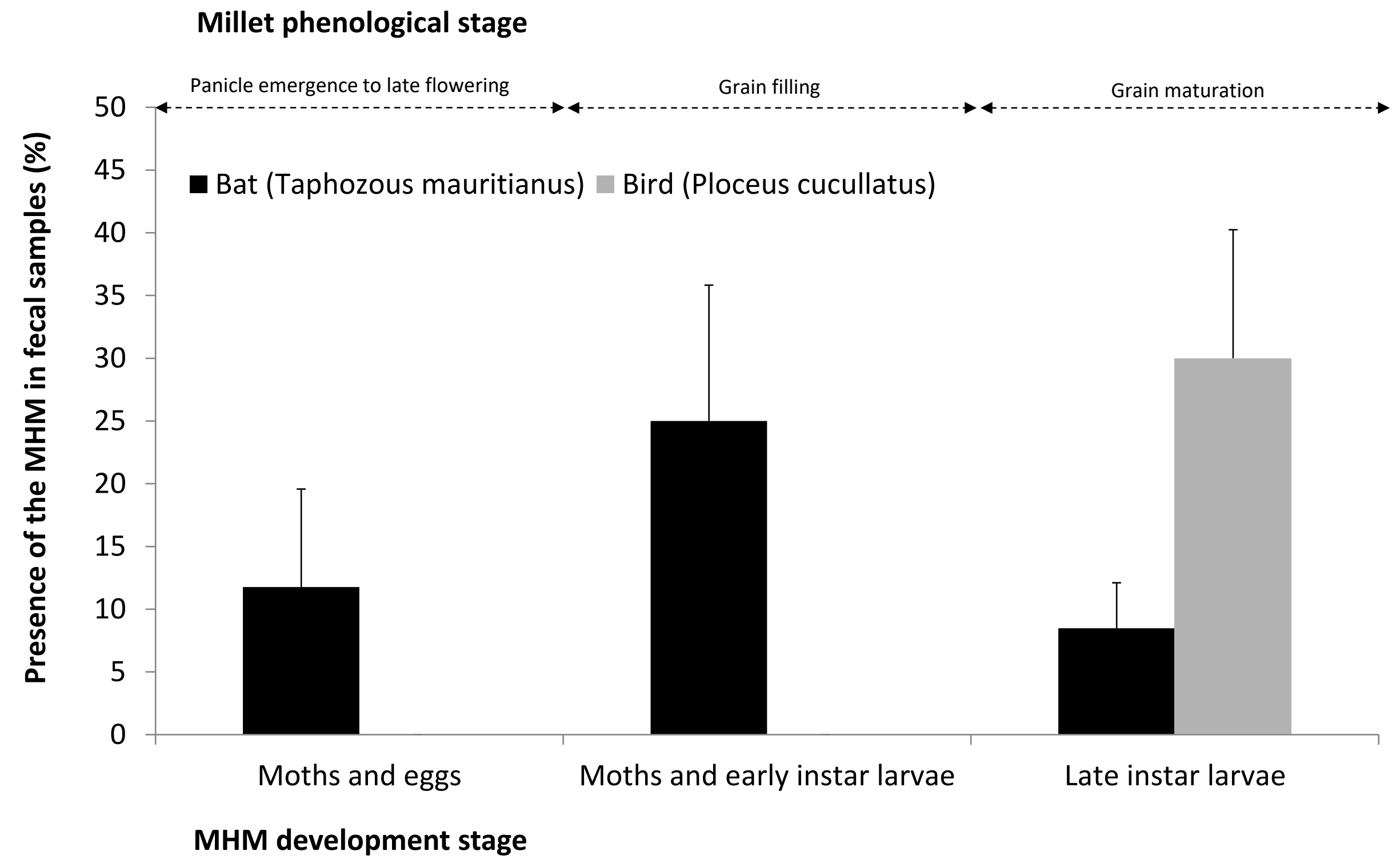


A

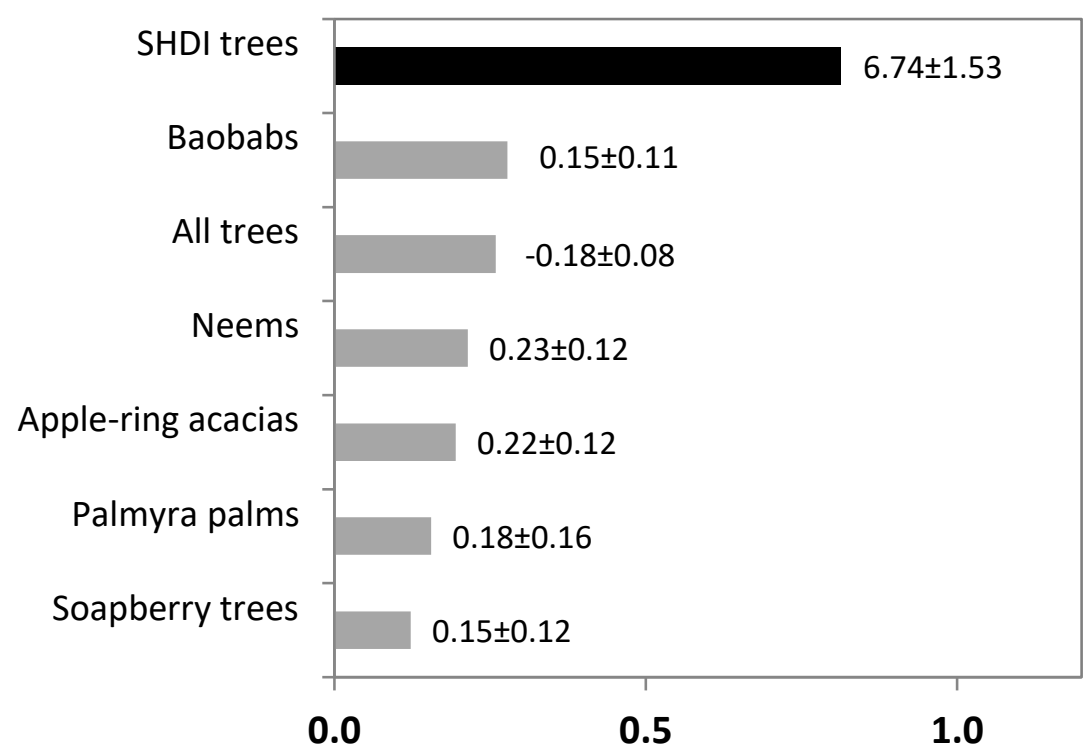

B

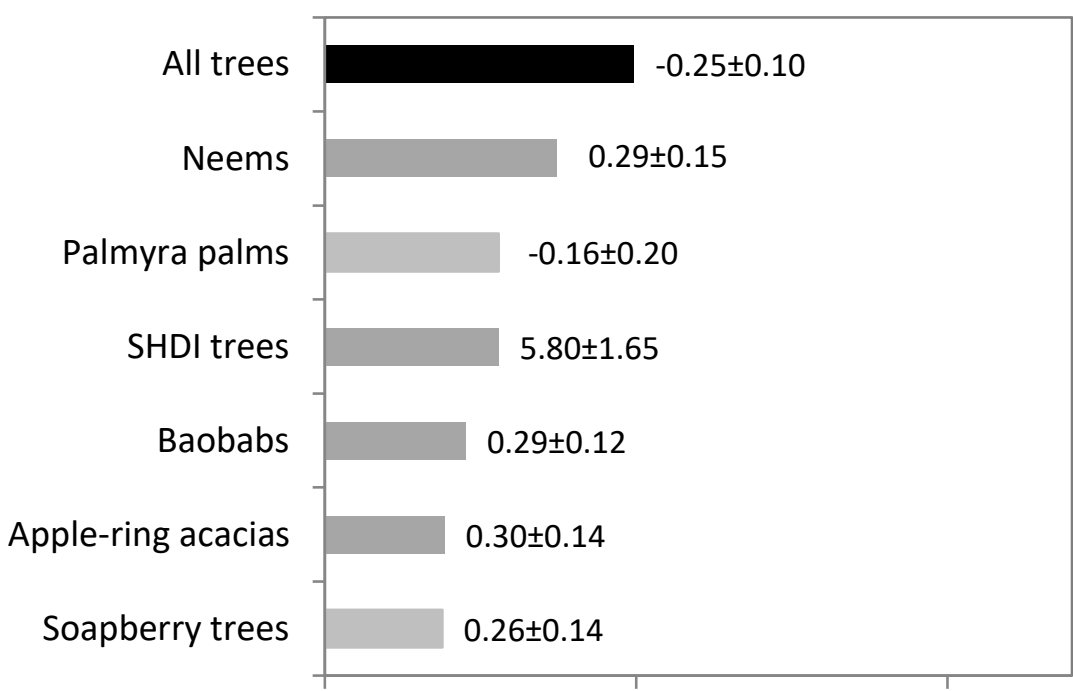
0.0
0.5
1.0

C

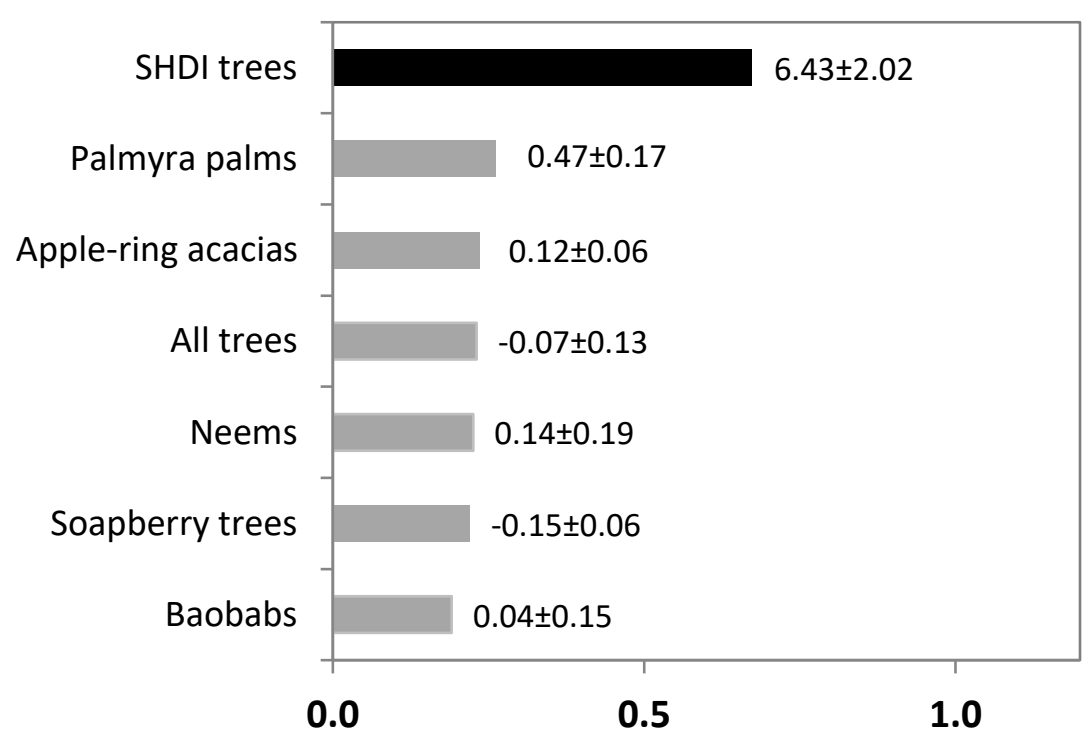

Relative variable importance 


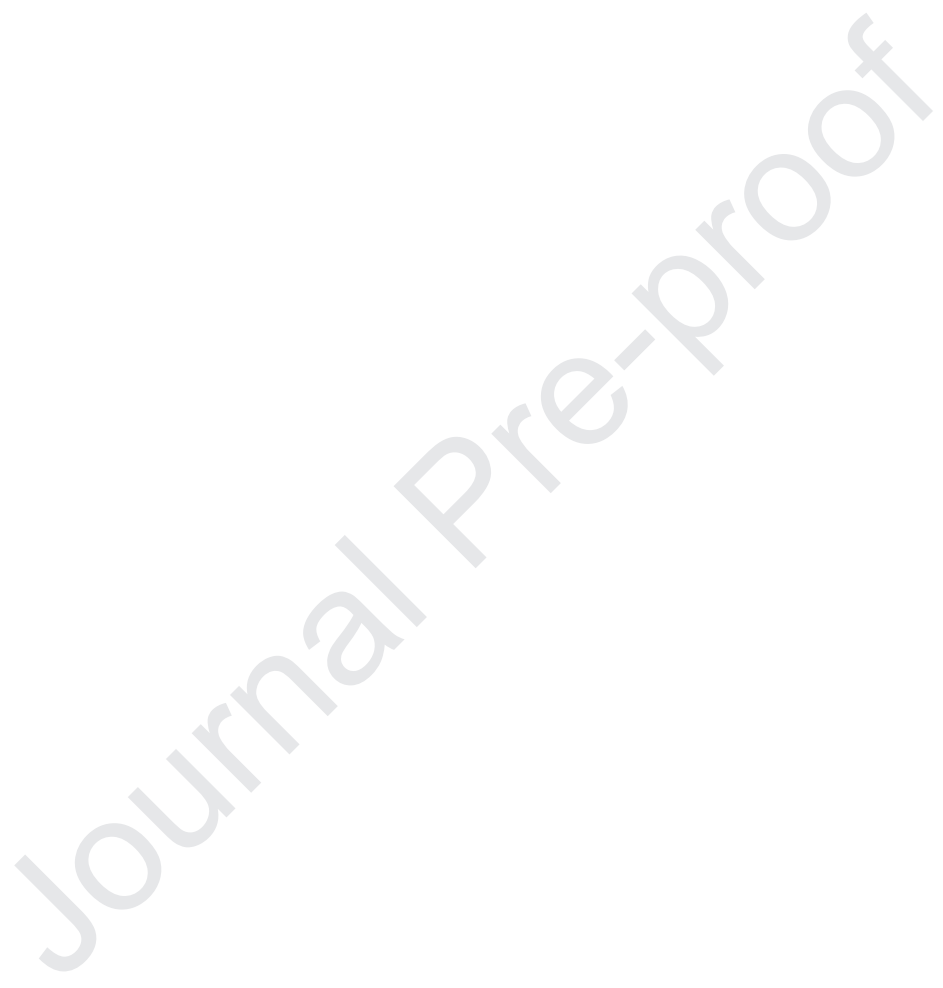


A

\section{All insectivorous birds}

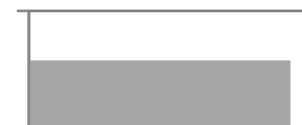

$-0,13 \pm-0,11$

Village weavers

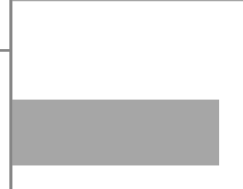

$-0.26 \pm 0.22$

Grey-headed sparrows

SHDI birds

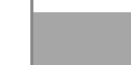

$0.01 \pm 0.00$

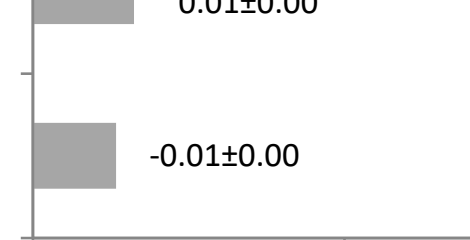

0.0

0.5

1.0

B

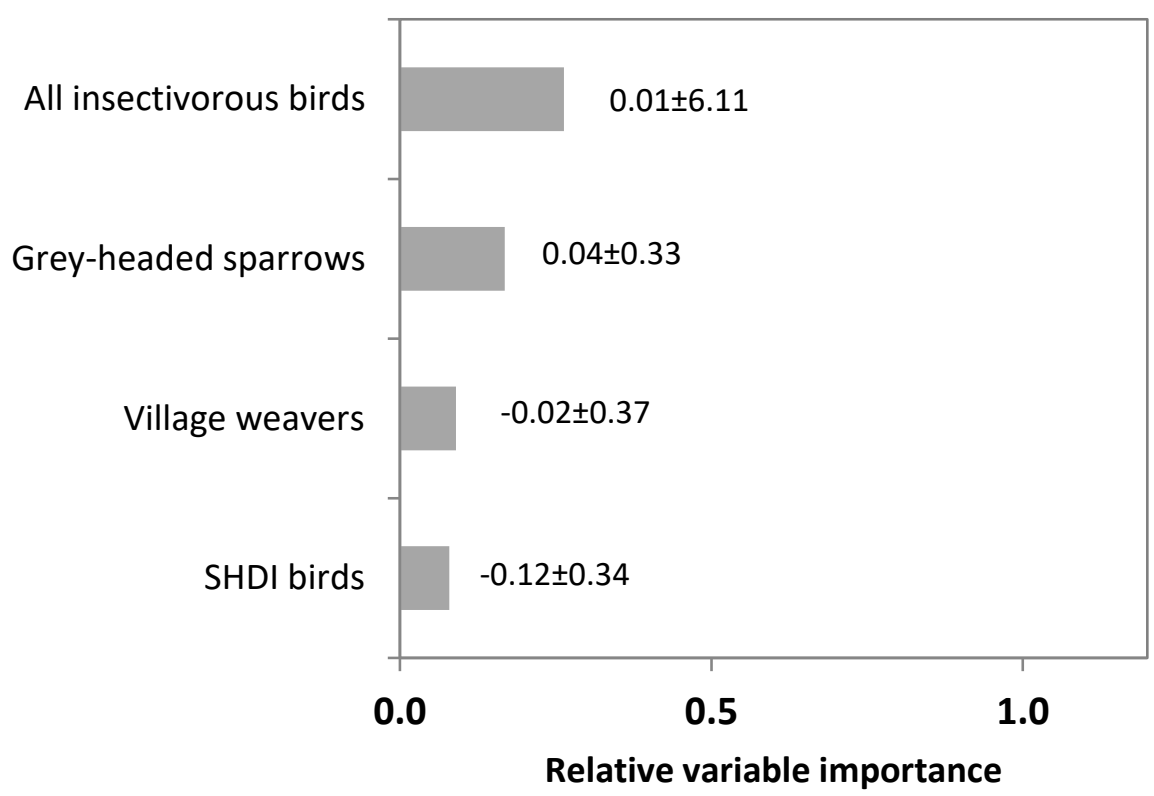




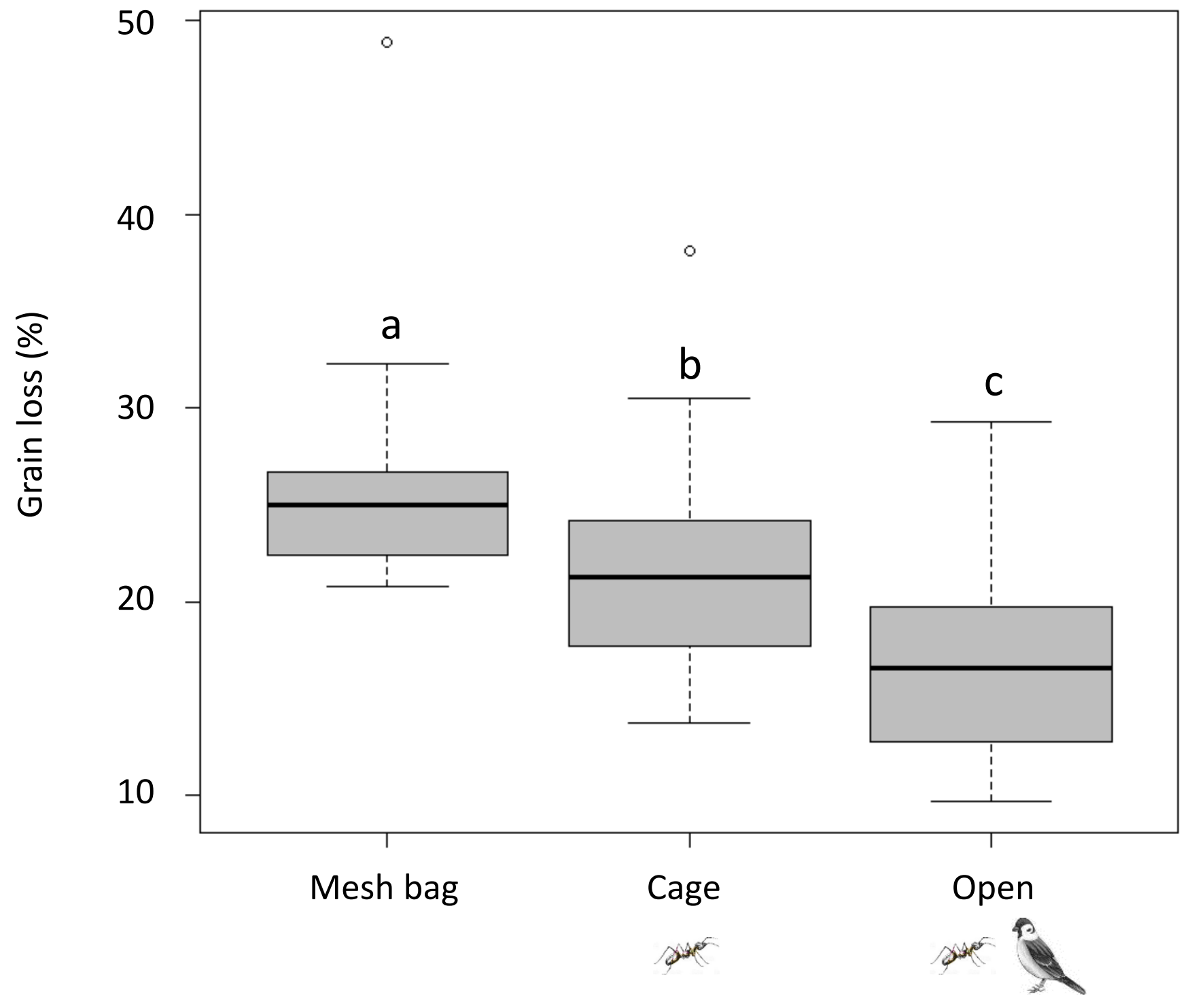


A

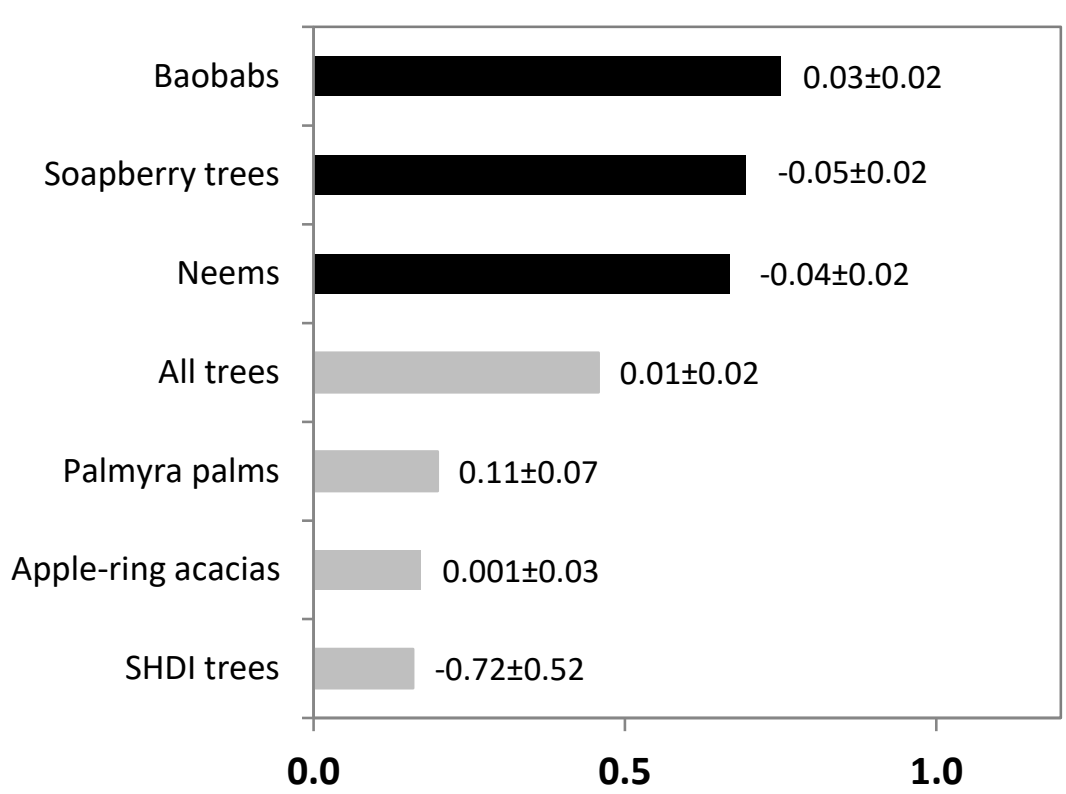

B

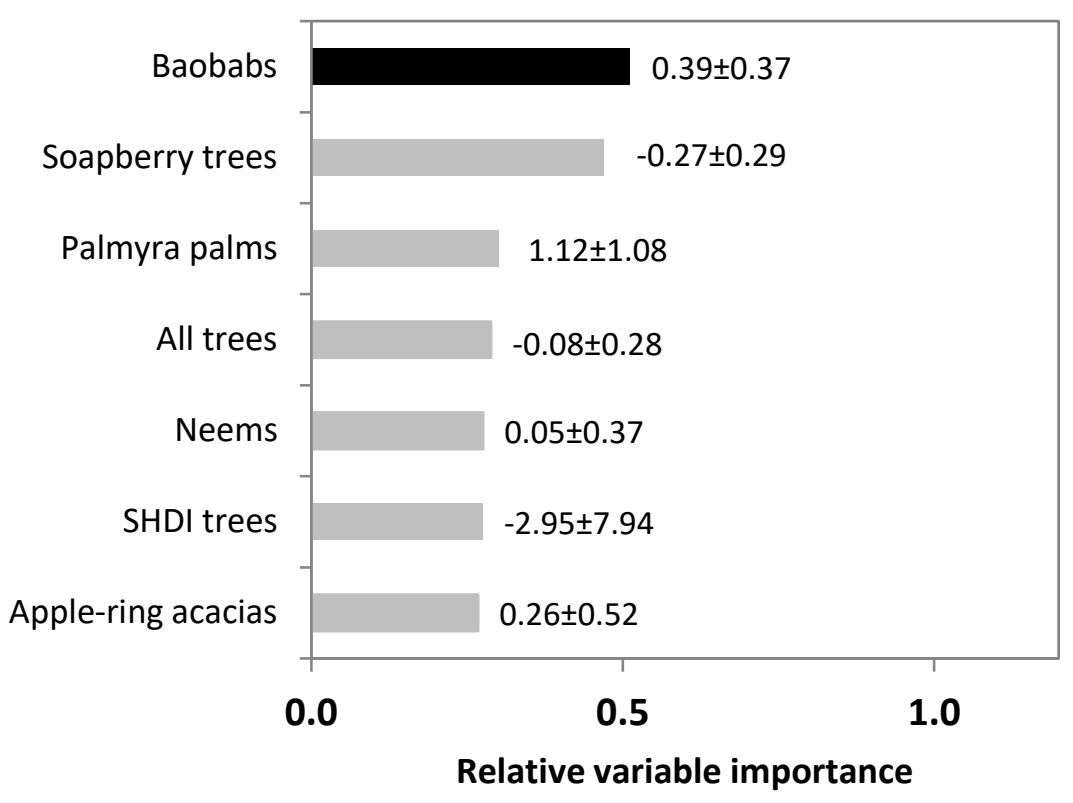




\section{Highlights}

- Vertebrates, including birds and bats, are effective predators of the millet head miner.

- They contribute to natural pest control and reduction of millet grain loss.

- The abundance of insectivorous birds is enhanced by tree diversity at a local scale.

- The contribution of trees for natural pest control is species-dependent. Trees can serve as refuges for pest (eg. baobab/moths) and predators (eg. palm tree/bats or neem/village weavers).

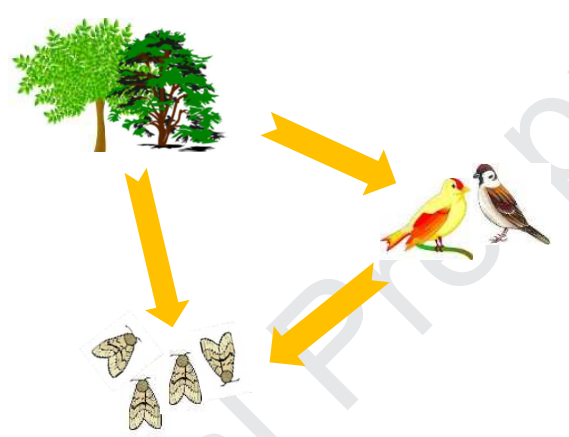




\section{Declaration of interests}

$\bigotimes$ The authors declare that they have no known competing financial interests or personal relationships that could have appeared to influence the work reported in this paper.

$\square$ The authors declare the following financial interests/personal relationships which may be considered as potential competing interests: 